\title{
AR 2997
}

\section{Re-Envisioning Distributed Collections in German Research Libraries - A View from the U.S.A.}

Kizer Walker, Ph.D.

Director of Collections

Cornell University Library (Ithaca, New York)

Abstract: German research libraries are undergoing a major shift as the distributed system of "Special Subject Collections" (Sondersammelgebiete) supported by the German Research Foundation (DFG) transitions to a new, restructured program of "Specialized Information Services for Research" (Fachinformationsdienste für die Wissenschaft). Many of the structural issues underlying the programmatic changes in German libraries are also at work in U.S. research libraries. This article reflects on the parallels and differences in approaches to cooperative collection development in U.S. and German research libraries and reports on an ongoing discussion between the DFG and the Center for Research Libraries (CRL), a library consortium based in Chicago that supports international collections in libraries in and outside the U.S.

Keywords: United States; research library; collaborative collection development; Center for Research Libraries; CRL; German Research Foundation; DFG

Eine Umgestaltung der verteilten Sammlungen in deutschen Forschungsbibliotheken - Ein Blick aus den USA

Wissenschaftliche Bibliotheken in Deutschland befinden sich in einem grundlegenden Wandel als das DFG-geförderte System von verteilten Sondersammelgebieten zum neuen umstrukturierten Programm "Fachinformationsdienste für die Wissenschaft" wechselt. Viele strukturelle Kräfte, die den programmatischen Veränderungen in deutschen Bibliotheken zugrunde liegen wirken auch auf die USForschungsbibliotheken. Dieser Artikel reflektiert über die Parallelen und Unterschiede im Herangehen an kooperativen Bestandsaufbau in US-amerikanischen und deutschen Forschungsbibliotheken und berichtet über eine laufende Diskussion zwischen der DFG und dem Center for Research Libraries (CRL), ein Bibliothekskonsortium mit Sitz in Chicago, das internationale Sammlungen in Bibliotheken in- und außerhalb der USA unterstützt.

SW: Vereinigten Staaten; wissenschaftliche Bibliothek; kooperativer Bestandsaufbau; Center for Research Libraries; CRL; Deutsche Forschungsgemeinschaft; DFG 
The past five years or so have witnessed an intense drive on the part of libraries in the United States to join forces in building and managing research collections. Collaborative collection development is not new to U.S. research libraries. Library consortia, mostly regionally-based, play an invaluable role in negotiating favorable terms for their members for licensed electronic content. This vital function of amplifying the buying power of individual libraries is distinct from a strategy of rationalizing acquisitions among a library network by distributing collection responsibilities by subject or other characteristics. Collaborative collection development in this latter sense has been more problematic in the U.S. context. There are several notable, longstanding regional partnerships and initiatives in particular subject areas, and there is a decades-long history of ambitious attempts to coordinate print-based collection development activities at a national level. Historically, however, the most successful initiatives of this kind have been relatively small in scale or narrow in scope and focus. It was above all the economic crisis of 2009 that introduced a new sense of urgency regarding more systematic and larger-scale collaboration around both print and electronic collections, as severe budget pressures challenged the time-honored collection development priorities of even the largest individual research libraries. But immediate economic necessity only served to spotlight ongoing changes in the nature and purposes of research library collections - the maturation of electronic resources, changing usage patterns for print collections, expanding global publishing output, broad changes in the higher education sphere - that make new forms of collaboration both possible and increasingly imperative. The title of a well-attended session at the 2010 American Library Association (ALA) Annual Meeting acknowledged a history of good intentions and at the same time signaled a break with past false starts and vacillations: "Cooperative Collection Development: We Really Mean It This Time."

In the same timeframe and driven, no doubt, by many of the same factors, German libraries were reexamining an established national framework for cooperative collection development, the Special Subject Collections (Sondersammelgebiete or SSG) system that, over a sixty-year period, shaped a distributed research collection intended to ensure comprehensive coverage of world scholarship in the libraries of the Federal Republic of Germany. As will be well known to German readers of Bibliothek: Forschung und Praxis, in 2010 and 2011 the German Research Foundation (DFG), the national funding agency that supported the distributed SSG collection, conducted a major evaluation study of the SSG 
program. ${ }^{1}$ The recommendations of the evaluators have already led to major changes in German system, changes that are still ongoing. ${ }^{2}$

\section{Starting a transatlantic dialogue}

The parallels as well as the discontinuities between the U.S. and German developments would seem to define a space for exchange that could be stimulating for both sides. One avenue for such an exchange opened in 2013 with the start of an ongoing conversation between the DFG and the Center for Research Libraries (CRL) that led to a meeting at the German National Library in Frankfurt in October 2014. Based in Chicago, CRL is an international consortium of university, college, and independent research libraries that specializes in making primary source materials from throughout the world, particularly resources that are difficult to obtain or that are vulnerable, available to its member libraries. ${ }^{3}$ CRL sponsors several initiatives aimed at improving access to research materials from various parts of the world, including the German-North American Resources Partnership (GNARP), which supports the acquisition of Germanlanguage materials, particularly electronic resources, among North American research libraries and promotes collaboration with German libraries. ${ }^{4}$

As chair of GNARP at the time, I approached the DFG in the hope of initiating a discussion among U.S. and German colleagues about transformations to the German system and opportunities for collaboration that this process might create. The immediate occasion for GNARP's engagement with the SSG discussion was a December 2012 conference on "The Global Dimensions of Scholarship and Research Libraries" ${ }^{5}$ co-sponsored by CRL and Duke University and supported by a grant from The Andrew W. Mellon Foundation. Held on the Duke campus in Durham, North Carolina, and billed as "A Forum on the Future," the event focused on ways to expand the collective capacity of research libraries

to represent and fuel globalized scholarship and sought, as well, "to inject an international focus into the current conversations regarding the future of research libraries in the digital age." The Global Forum produced a report (available at the CRL website ${ }^{6}$ ) with three main recommendations, all relevant to the SSG discussion. U.S. research libraries, Forum participants advised, should: "aggressively pursue broad digital access to international information resources"; "internationalize research library services and perspectives"; and "broaden and internationalize library collaborations." Each of these broad goals incorporates several detailed objectives. The third one, on international collaborations, includes the following recommendation: "Explore collaborations that have arisen in other countries and regions (for 
example Germany's distributed responsibilities for area acquisitions. . .) as a basis for their further extension and also as possible models for new regional or international initiatives."7

The 2014 meeting in Frankfurt, held on the heels of the Book Fair in October, brought together representatives of the DFG, librarians from SSG partner institutions, and representatives of CRL and GNARP. The purpose of the encounter was primarily informational for both the German and American sides. The evolving framework for DFG support of German research library collections was a key topic of discussion. But participants considered collaborative collecting in the broadest sense, including collection sharing, resource development, digitization and digital archiving programs, and new service models for user-focused collection development, drawing on German and U.S. experiences. A particular focus was comparing multi-institutional approaches to coordinating electronic resource licensing in the two countries.

German and U.S. participants agreed that this preliminary meeting warranted a continuation of the discussion with an eye toward points of collaboration with tangible benefits for both sides. Sharing perspectives and expertise on electronic resource licensing appears to be a potentially fruitful future direction. Other areas of interest to explore include possible collaboration on improving access and to German and U.S. news resources and on news media archiving. There is talk of follow-up meetings in the U.S. in 2015 and options for broadening the conversation to include U.S. library participants beyond CRL.

\section{From Special Subject Collections to Specialized Information Services}

A short review of the DFG-funded distributed collection programs will be useful for non-German colleagues. ${ }^{8}$ As the DFG defines it, "[t]he purpose of cooperative acquisition is to provide in Germany at least one copy of each scientifically relevant work, catalogue it, and make it accessible nationwide for the long term." The West German SSG program was established to this end in 1949, with a focus on acquisition of materials published outside the country. In this immediate postwar context, the program was intended to compensate for the significant gaps that developed in German research libraries over twelve years of neglect and isolation under National Socialism as well as to rebuild collections lost in the war. Responsibility for comprehensive acquisition of the international research literature was divided, by subject, among 25 libraries. By 2010, when the DFG evaluation of the program was undertaken, 36 German research libraries maintained SSG collections in 110 subject areas; 27 of these libraries received 
DFG support for acquisitions in 86 subject areas with grants covering $75 \%$ of expenditures on foreign publications. $^{9}$

The 2010-11 evaluation of the SSG program underscored a growing misalignment between the existing system of distributed collection responsibilities and the quickly shifting research and scholarly communications environment. Among the recommendations of the external evaluators was that libraries give priority to acquisition of electronic resources and develop services to fully integrate them into research offerings. Evaluators also urged closer, ongoing dialogue between libraries charged with special subject responsibilities and the researchers who use the collections. Closer engagement with user communities would foster more tailored research services and allow libraries to refocus collection development activities on researchers' immediate needs. This would entail a shift from a "just-in-case" approach to acquisitions - the prospective approach aimed at comprehensive coverage that had characterized collection building in the SSG context - to a more targeted use of funds. In addition, evaluators advised reducing duplication of acquisitions with other German institutions charged with building specialized subject collections.

Most of the recommendations of the evaluators are reflected in DFG's restructured funding program for distributed subject collections. The intensified focus on user communities informs the program's "mission," which is "redefined to allow greater responsiveness to subject-specific interests as well as to enhance access to digital publications substantially. ${ }^{10}$ Significantly, the restructured program moves away from an undifferentiated ideal of comprehensive collections. The degree to which collecting is pursued on a just-in-time or just-in-case basis is also a matter of discipline-specific needs identified in dialogue with users:

Whereas this task is no longer subject to the primacy of completeness, anticipatory collection building based on the requirements of particular research communities is still an option. The principles of serving a subject area will therefore no longer be uniform across all disciplines but defined independently by each library in dialogue with the respective research community (DFG Committee 6).

Regarding format, DFG support in the new program imposes a strong e-preferred policy, mandating electronic whenever a publication is available in both print and electronic forms. 
The new funding program has been rebranded, discarding the old term "Special Subject Collections" (Sondersammelgebiete) in favor of "Specialized Information Services for Research"

(Fachinformationsdienste für die Wissenschaft, or FID). Libraries with subject emphases in the old SSG system are not automatically transferred to the new program, rather they have to reapply for FID funding in a process that is proving to be quite rigorous and selective. The transition to the new Specialized Information Services framework is foreseen as a three-year process (2013-2015) with a new round of proposals reviewed each year. The first five Specialized Information Services grants were awarded in December 2013 for the following subjects: Law (Berlin State Library), Criminology (Tübingen University Library), Art History (Heidelberg University Library and Saxon State and University Library Dresden), Media and Communication Studies (Leipzig University Library), and Music Studies (Bavarian State Library, Munich). ${ }^{11}$

Since the mid-2000s, the DFG has systematically supported German research libraries in licensing electronic resources. The initial focus was on national licenses for journal back files and other selfcontained resources, which were fully funded by the DFG. Since 2010, the program has shifted from this national licensing model to a so-called "alliance license" model in which individual institutions can opt in on consortial licenses brokered by the DFG; in the alliance model, which covers ongoing electronic serial subscriptions and other continuations, the DFG contributes a portion of the cost, which is mainly born by the licensing institution. ${ }^{12}$ Both of these DFG licensing programs are distinct from the SSG and Specialized Information Services programs. However, FID funding is accompanied by guidelines for licensing electronic resources in the respective subject specializations - and these stipulate that libraries seek license provisions that grant access to specialists in the relevant subject communities, who may have a variety of institutional affiliations. ${ }^{13}$ The Berlin State Library has been successful in negotiating this sort of community licensing for electronic resources in East Asian Studies, which are accessible upon registration to "[i]ndividuals (such as teachers, researchers, students etc.) affiliated to a German institution" in the Berlin State Library's interlibrary loan network for East Asian materials. ${ }^{14}$ The latitude for developing the emerging community license model will necessarily vary by subject area, publisher, and size of the specialist user community (the larger the potential pool of users, the less flexible the licensing terms, presumably). But the inclusion of the community aspect in the licensing guidelines for resources supported in the FID program could provide the pressure that will be needed to expand this licensing model. 


\section{The U.S. context for collaborative collection development}

From the perspective of a U.S. research librarian, the SSG system and its recent reconfiguration feel both strange and familiar. The network of U.S. research libraries is so heterogeneous in terms of the histories, missions, sizes, assets, and constituents of the institutions in which they are embedded that a centrally funded, nationally-coordinated system of collaborative collection development on the scale of the old SSG program was never a possibility here. And yet, U.S. research libraries have their own strong history of collaborative collection development that parallels the German experience in many ways. And the contours of the new Specialized Information Services program emerging in the German context today mirror ongoing shifts in U.S. libraries from a focus on collections as such to a broad concept of services to support research, services that demand closer and more dynamic collaboration with researchers and with other institutions.

Several of the initiatives and associations that have supported collaboration among U.S. libraries date, like the German SSG system, to the post-Second World War era and the Cold War years. The predecessor organization to CRL was founded in 1949, the same year the SSG program was established. The so-called Farmington Plan was initiated in 1942, originally conceived, like the SSG program, as a means of addressing wartime disruptions in the supply of international publications to libraries. Sponsored by the Association of Research Libraries (ARL) from the mid-1940s until the program was discontinued in 1972, the Farmington Plan was as an ambitious attempt to coordinate acquisition of foreign publications on a national scale, though it ultimately fell far short of its goals. ${ }^{15}$

Governmental programs like the Title VI grants program of the U.S. Department of Education, which funds the network of U.S. National Resource Centers (NRCs) for world area studies, have included essential funding for library collections at NRC institutions. Drastic cuts in recent years have significantly reduced the role of Title VI in maintaining U.S. research collections. Another example is the Public Law (PL) 480 acquisitions program overseen by the Library of Congress from the early 1960s to the mid1990s, which primarily assisted libraries in acquiring South Asian materials. ${ }^{16}$

Initiatives such as the RLG Conspectus of the 1980s also have aspects in common with the former SSG system. The Conspectus project sought to describe and assess collection strengths in North American research libraries (and the method was adopted by libraries around the world). ${ }^{17}$ The Conspectus was not a plan for coordinating acquisitions, but the national inventory of collection strengths was viewed as 
a foundation for collaborative collection development efforts. By the 2000s, however, the print bias of the instrument and - maybe more importantly - the underlying assumption that the "strength" of library holdings could be uniformly measured across institutions, dissociated from specific user communities, rendered the Conspectus less relevant in the changing research and information environment.

If coordination on a national scale has proven elusive in the U.S. context, regional collaborations among small groups of libraries have a history of success. The Triangle Research Libraries Network (TRLN) in North Carolina has coordinated collection development activities among three (and later four) universities since 1980 (and traces its development to inter-institutional partnerships formed in the 1930s). More recently, Cornell University Library in Ithaca, New York, has embarked on a "deep partnership" with Columbia University Library in New York City and this "2CUL" model, which includes close collaboration in the library technical services area as well as coordinated collection development in certain fields, has garnered a great deal of attention nationally. ${ }^{18}$ Cornell and Columbia are also members of the broader, but still circumscribed, Borrow Direct library consortium (which encompasses Brown, Columbia, Cornell, Duke, Harvard, Princeton, Johns Hopkins, and Yale Universities; Dartmouth College, the Massachusetts Institute of Technology, the University of Pennsylvania, and the University of Chicago). Borrow Direct has successfully shared resources for several years in an enhanced interlibrary loan arrangement and is now experimenting with collaborative collection development initiatives though on a small scale up to now.

It seems clear that efforts will need to scale up significantly and soon, and this means that individual libraries will have to come to terms with relinquishing a degree of local control over acquisitions in order to achieve more rational and sustainable means of providing access to resources for research. In 2012 , a task force of the Association of Research Libraries (ARL) Steering Committee on Transforming Research Libraries published a set of high-level propositions about the immediate future of research library collections. Among the conclusions was the following:

In a networked world, local collections as ends in themselves make learning fragmentary and in complete. Twenty-first-century collection management will therefore require increased collaboration within and among institutions, as well as a shift from thinking of collections as products to understanding collections as components of the academy's knowledge resources. A multi-institutional approach is the only one that now makes sense. ${ }^{19}$ 


\section{E-resource licensing and other collection development concerns}

Where U.S. libraries have been consistently successful over the past two decades in terms of collaborative, multi-institutional collection development is in consortial negotiations for electronic resource licensing. To name two major players in this field: The NorthEast Research Libraries Consortium (NERL) has a longstanding role in successfully pressing for favorable terms and jointly licensing electronic resources for nearly 30 large and many smaller member libraries (established in 1996, NERL has been sponsored by CRL since 2013). ${ }^{20}$ The California Digital Library (CDL), a unit of the University of California, offers a wide range of digital library services, with a key focus on electronic resource licensing. CDL has been highly effective in acquiring statewide consortial licenses for the ten research institutions that make up the University of California system. ${ }^{21}$ The Liblicense project has played a crucial role in supporting consortial efforts such as these since the late 1990s by developing and disseminating expertise in electronic scholarly resource licensing for North American libraries, including a highly influential model license in 2001. A new version was released in late 2014. Developed with support of The Andrew W. Mellon Foundation under the auspices of CRL, in partnership with several prominent library organizations, the new Liblicense Model License Agreement is intended as a template for use in licensing negotiations agreements, but also, importantly, "as a statement by the academic library community of what it considers acceptable policy and practice for licensing digital information."22

From my standpoint as a self-confessed outsider, one of the most interesting ideas to emerge in the context of the ongoing shift to Specialized Information Services in German libraries is the "community license" model mentioned above. This is the model - clearly still new and very much in formation - in which institutions with national responsibility for particular subject areas seek to negotiate access for specialist researchers in Germany in regardless of their institutional affiliation. It is an idea that I have not encountered in the U.S. library environment and this suggests that further transatlantic discussion of licensing models could be very productive, hopefully for both sides. Perhaps there will prove to be room for coordinating licensing collaborations between German FID libraries and U.S. libraries with strong collections in analogous fields. I can imagine that the German research library experience might help stimulate U.S. libraries to better integrate our thinking about e-resource licensing issues and broader print and electronic collection development concerns.

At its best, the decentralized U.S. system with its multiple, sometimes overlapping alliances among libraries, has fostered flexibility and experimentation in approaches to shared collection building across 
institutions. The German experience, with the strong coordinating role of the DFG, offers a more comprehensive, perhaps more holistic perspective on the collective provision of resources for research. Closer connections and more opportunities for ongoing dialogue can only strengthen the research environment that both countries share.

Kizer Walker, Ph.D.

Director of Collections

Cornell University Library

310 Uris Library Cornell

University

Ithaca, NY 14853

USA

kw33ecornell.edu

${ }^{1}$ Full documentation of the evaluation process is available on the website of the Deutsche Forschungsgemeinschaft (DFG):

http://www.dfg.de/dfg_profil/foerderatlas_evaluation_statistik/programm_evaluation/studien/studie_ sondersammelgebiete/.

${ }^{2}$ Elisabeth Niggemann, et al. "Evaluierung des von der Deutschen Forschungsgemeinschaft geförderten Systems der Sondersammelgebiete. Empfehlungen der Expertenkommission SSG" (9 March 2011): http://www.dfg.de/download/pdf/dfg_im_profil/evaluation_statistik/programm_evaluation/studie_eva luierung_sondersammelgebiete_empfehlungen.pdf.

${ }^{3}$ See: http://www.crl.edu/about.

${ }^{4}$ See: http://www.crl.edu/grn/gnarp.

${ }^{5}$ The conference program and related documentation is available on the website of the Center for Research Libraries (CRL): http://www.crl.edu/events/8478.

6"The Global Dimensions of Scholarship and Research Libraries: Finding Synergies, Creating Convergence" (April 2013):

http://www.crl.edu/sites/default/files/attachments/events/Global\%20Forum\%20Recommendations.pdf

7 “The Global Dimensions of Scholarship and Research Libraries” (my emphasis) 6.

${ }^{8}$ A recent German-language publication provides a detailed overview of collaborative collection development in Germany: Katharina Hundhammer, Kooperativer Bestandsaufbau und überregionale Literaturversorgung in Deutschland, Berliner Handreichungen zur Bibliotheks- und Informationswissenschaft 364 (Berlin: Institut für Bibliotheks- und Informationswissenschaft der Humboldt-Universität zu Berlin, 2014): http://edoc.hu-berlin.de/series/berliner-handreichungen/2014364/PDF/364.pdf. 
${ }^{9}$ Christoph Kümmel and Anke Reinhart, "Information Services of the Future: What is the Contribution of Special Subject Collections in German Libraries?" DFG Infobrief: Research Funding - Facts and Figures 2.11 (2011): 2.

http://www.dfg.de/download/pdf/dfg_im_profil/evaluation_statistik/programm_evaluation/ib02_2011 en.pdf

${ }^{10}$ DFG Committee on Scientific Library Services and Information Systems, Taking Digital Transformation to the Next Level: The Contribution of the DFG to an Innovative Information Infrastructure for Research, Deutsche Forschungsgemeinschaft Strategy Paper (3 July 2012) 5.

http://www.dfg.de/download/pdf/foerderung/programme/lis/strategy_paper_digital_transformation.p df. Or see German-language version: Die digitale Transformation weiter gestalten. Der Beitrag der Deutschen Forschungsgemeinschaft zu einer innovativen Informationsinfrastruktur für die Forschung: http://dfg.de/download/pdf/foerderung/programme/lis/positionspapier_digitale_transformation.pdf.

11 "Specialised Information Services: DFG boosts library services for researchers," Press Release 54 (20 December 2013):

http://www.dfg.de/en/service/press/press_releases/2013/press_release_no_54/index.html; Germanlanguage version: "Fachinformationsdienste: DFG stärkt Dienstleistungen der Bibliotheken für die Wissenschaft":

http://www.dfg.de/service/presse/pressemitteilungen/2013/pressemitteilung_nr_54/index.html. See also "Übersicht zu den Antragsgruppen zur schrittweisen Überführung der bestehenden 'Sondersammelgebiete' in das System der 'Fachinformationsdienste für die Wissenschaft'" (15 October 2012) DFG:

http://www.dfg.de/download/pdf/foerderung/programme/lis/fachinformationsdienste_antragsgruppe n.pdf.

12 “Allianz-Lizenzen,” DFG-geförderte nationale Lizenzen für elektronische Medien Staatsbibliothek zu Berlin - Preußischer Kulturbesitz: https://www.nationallizenzen.de/ueber-nationallizenzen/allianzlizenzen-2011-ff.

13 "Grundsätze für den Erwerb von Publikationen im DFG-geförderten System der Fachinformationsdienste für die Wissenschaft," DFG:

http://www.dfg.de/formulare/12_101/12_101_de.pdf. See also "Nationale Lizenzierung im Kontext der DFG-geförderten Sondersammelgebiete," DFG-geförderte nationale Lizenzen für elektronische Medien. Staatsbibliothek zu Berlin - Preußischer Kulturbesitz: https://www.nationallizenzen.de/uebernationallizenzen/ueber-nationale-lizenzen-dfg-gefoerderte-nationale-lizenzen-fuer-elektronischemedien.

${ }^{14}$ See "Registration - Terms of Use," CrossAsia, Staatsbibliothek zu Berlin: http://crossasia.org/en/meinxasia/registrierung.html.

${ }^{15}$ See James Burgett, et al., Collaborative Collection Development: A Practical Guide for Your Library (Chicago: American Library Association, 2004) 11; also Ralph D. Wagner, A History of the Farmington Plan (Lanham, Maryland: Scarecrow Press, 2002).

16 "History of Cooperative Collection Development for South Asia," CONSALD (Committee on South Asian Libraries and Documentation): http://consald.org/node/525. 
17 "Creating the Conspectus," OCLC: http://oclc.org/research/activities/conspectus.html. See also Burgett 12-13.

${ }^{18}$ See: https://www.2cul.org/.

${ }^{19}$ Deborah Jakubs, Tom Leonard, et al., "21st-Century Collections: Calibration of Investment and Collaborative Action," Issue Brief, Association of Research Libraries (March 10, 2012):

http://www.arl.org/storage/documents/publications/issue-brief-21st-century-collections-2012.pdf.

20 “NERL History," NERL Consortium: http://nerl.org/nerl-history.

${ }^{21}$ See: http://www.cdlib.org/about/.

22 "CRL and Partners Publish New e-Resources Model License," News, Center for Research Libraries (3 December 2014): http://www.crl.edu/news/11103. The model license itself is available here: http://liblicense.crl.edu/licensing-information/model-license/. 